\title{
Corrigendum: A Genetic System for Methanocaldococcus jannaschii: An Evolutionary Deeply Rooted Hyperthermophilic Methanarchaeon
}

\author{
Dwi Susanti ${ }^{1}$, Mary C. Frazier ${ }^{1}$ and Biswarup Mukhopadhyay ${ }^{1,2,3 *}$ \\ ${ }^{1}$ Department of Biochemistry, Virginia Tech, Blacksburg, VA, United States, ${ }^{2}$ Biocomplexity Institute, Virginia Tech, \\ Blacksburg, VA, United States, ${ }^{3}$ Virginia Tech Carilion School of Medicine, Virginia Tech, Blacksburg, VA, United States
}

Keywords: genetics, ancient archaea, methanogen, hyperthermophile, anaerobe, Methanocaldococcus jannaschii, gene knockout, protein overexpression

\section{A Corrigendum on}

OPEN ACCESS

Edited and reviewed by:

Thomas J. Santangelo,

Colorado State University,

United States

*Correspondence:

Biswarup Mukhopadhyay

biswarup@vt.edu

Specialty section:

This article was submitted to

Microbial Physiology and Metabolism,

a section of the journal

Frontiers in Microbiology

Received: 03 January 2021 Accepted: 26 January 2021

Published: 09 March 2021

Citation:

Susanti D, Frazier MC and

Mukhopadhyay B (2021)

Corrigendum: A Genetic System for

Methanocaldococcus jannaschii: An

Evolutionary Deeply Rooted

Hyperthermophilic Methanarchaeon.

Front. Microbiol. 12:649127.

doi: 10.3389/fmicb.2021.649127
A Genetic System for Methanocaldococcus jannaschii: An Evolutionary Deeply Rooted Hyperthermophilic Methanarchaeon

by Susanti, D., Frazier, M. C., and Mukhopadhyay, B. (2019). Front. Microbiol. 10:1256. doi: 10.3389/fmicb.2019.01256

In the original article, the reference for Balch et al. (1979) was incorrectly written as Balch, W. E., and Wolfe, R. S. (1976). New approach to the cultivation of methanogenic bacteria: 2-mercaptoethanesulfonic acid (HS-CoM)-dependent growth of Methanobacterium ruminantium in a pressureized atmosphere. Appl. Environ. Microbiol. 32, 781-791. It should be Balch, W. E., Fox, G. E., Magrum, L. J., Woese, C. R., and Wolfe, R. S. (1979). Methanogens: reevaluation of a unique biological group. Microbiol. Rev. 43, 260-296.

The $2 \mathrm{~L}$ steel anaerobic canister used in our study was a modified version of a pressure cylinder described in Figure 5 of the above-mentioned publication (Balch et al., 1979). The length or the height of the modified unit was $17.5 \mathrm{~cm}$.

The authors apologize for this error and state that this does not change the scientific conclusions of the article in any way. The original article has been updated.

\section{REFERENCES}

Balch, W. E., Fox, G. E., Magrum, L. J., Woese, C. R., and Wolfe, R. S. (1979). Methanogens: reevaluation of a unique biological group. Microbiol. Rev. 43, 260-296.

Copyright $(2021$ Susanti, Frazier and Mukhopadhyay. This is an open-access article distributed under the terms of the Creative Commons Attribution License (CC BY). The use, distribution or reproduction in other forums is permitted, provided the original author(s) and the copyright owner(s) are credited and that the original publication in this journal is cited, in accordance with accepted academic practice. No use, distribution or reproduction is permitted which does not comply with these terms. 